Dominican gull

Magellan (dolphin) gull

Falkland skua

Short-eared owl

Red-footed owl

Barn owl

Tussac bird

Garnot's ground-tyrant

Grass wren

Cobb's wren

Falkland thrush

Falkland pipit

Military starling

Siskin

Black-throated finch

House sparrow
Larus marinus dominicanus

Leucophaeus scoresbii

Stercorarius skua*

Asio flammeus sanfordi

Strix rufipes

Tyto alba

Cinclodes antarcticus*

Muscisaxicola m. macloviana*

Cistothorus platensis hornensis *

Troglodytes musculus cobbi*

Turdus $f$. falcklandii*

Anthus correndera trayi*

Pezites militaris falklandicus*

Carduelis barbatus

Melanodera $m$. melanodera*

Passer domesticus

\title{
Death in the Jungle
}

The Bolivian delegate, to an FAO meeting of foresters in Rome last year, Federico Bascope, told this story.

'Eight years ago, 600 people in the village of San Ramon in Beni State, deep in the Bolivian jungles, died of a strange disease. Appealed to by the authorities, the American Institute of Tropical Diseases in Panama sent a party of researchers who, after a two-year stay in San Ramon, diagnosed haemorrhagic fever, an extremely dangerous disease, widespread in small mammals, which had most probably been brought into the village by the numerous rats, mice and other rodents.

'Further investigation revealed that the unusual number of rodents both in the village and in the jungle around it was probably caused by a sharp decrease in the numbers of their natural predators. Jaguars, pumas and ocelots were once abundant in the jungles of this region but are now almost extinct thanks to continual, ruthless hunting by local people who sell the skins to foreign tradesmen. These traders, mainly from Argentina, can land their own aircraft unnoticed at any time on one of the 600-odd airstrips of the Amazon region and take off again with a planeload of skins. Two years ago Bolivia passed a law prohibiting the hunting of these jungle cats, but the profits are too tempting to poor peasants. Between 3,000 and 4,000 jaguars are killed by poachers each year in Bolivia.'

Mr. Bascope urgently requested FAO to help, demanding action at the international level. As the frontiers of three other countries Argentina, Chile and Peru - meet Bolivia on the high plateau the problem called for common planning and participation, and Bolivia, he said, was trying to interest the others in a joint request to FAO to establish a wildlife protection programme in the region. The problem became even more pressing when haemorrhagic fever struck again at San Ramon. Thirty cases were reported, 20 people died, and the village was quarantined. 'But how long can the disease be isolated?' Mr. Bascope asked. 'The cause is still widespread over the whole region. Jaguars and other felines are still being decimated.' 